\title{
Teacher Competencies through the Prism of Educational Research
}

\author{
Cirila Peklaj ${ }^{1}$
}

$\approx$ The present article focuses on teacher competencies as a major factor that impacts student learning. Ultimately, all attempts to improve education converge in the teacher and the quality of his/her work with students. With their teaching methods, their communication and their classroom management, teachers can structure the kind of learning environment that will either promote or hinder learning. The purpose of the article is to analyse research on educational productivity in order to select the most important teacher competencies that are related to student achievement. A model of teacher competencies is developed that serves as a framework for understanding the synergetic effects of teacher competencies on achievement thorough promoting students' cognitive, affective and social processes. The teacher competencies that impact each of the processes are described and their impact on student achievement is explained.

Keywords: teacher competencies, teaching strategies, (meta)cognitive processes, affective-motivational processes, social processes, student achievement 


\section{Učiteljeve kompetence skozi prizmo raziskav $\mathrm{v}$ izobraževanju}

\section{Cirila Peklaj}

$\approx$ Članek se osredinja na učiteljeve kompetence kot najpomembnejši dejavnik, ki pri učencih vpliva na njihovo učenje. Vsi poskusi izboljšanja izobraževanja se vedno končajo pri učitelju in kakovosti njegovega dela $\mathrm{z}$ učenci. S svojimi metodami poučevanja, komunikacijo, z vodenjem oddelka lahko učitelji oblikujejo tako učno okolje, ki bo spodbujalo ali pa zaviralo učenje. Namen prispevka je analizirati raziskave na področju produktivnosti v izobraževanju, da bi lahko izluščili najpomembnejše učiteljeve kompetence, ki so povezane $\mathrm{z}$ dosežki učencev. $\mathrm{V}$ ta namen smo razvili model učiteljevih kompetenc, ki služi kot okvir za razumevanje sinergičnih učinkov učiteljevih kompetenc na dosežke prek spodbujanja spoznavnih, čustvenih in socialnih procesov. Opisane so učiteljeve kompetence, ki vplivajo na posamezne procese, razložen pa je tudi njihov vpliv na dosežke učencev.

Ključne besede: učiteljeve kompetence, strategije poučevanja, (meta) kognitivni procesi, čustveno-motivacijski procesi, socialni procesi, dosežku učencev 


\section{Introduction}

Research on educational productivity emphasises the quality of teaching as one of the major factors influencing optimal student achievement (Hattie, 2009; Marzano, 2003; Walberg, 2006). In the knowledge society, expectations of teachers are very high. It is expected that they will have competencies for developing optimal learning environments for students and for promoting key competencies in students that will enable them to be successful in the rapidly changing society in the $21^{\text {st }}$ century. The OECD has suggested that the key competencies are the ability to work in heterogeneous groups in different contexts and situations, the ability to be autonomous in life and work regarding planning and decision making, and the ability to use symbolic systems such as language, mathematics and ICT (Rychen \& Salganick, 2001, 2003). In order to fulfil these expectations and develop optimal learning environments for students, teachers have to develop complex instructional, classroom management, communication and assessment competencies so as to facilitate students' cognitive, affective and social processes.

Nye, Konstantopoulos and Hedges (2004) estimated that teacher quality can explain between 7 and 21 percent of variance in student achievement. Research has also shown a difference of 39 percentage points in student achievement gains in one school year between students who spent a year with the most effective teachers and those who were taught by the least effective teachers: students with the least effective teachers registered gains of 14 percent, while those with the most effective teachers demonstrated gains of 53 percent (Haycock, 1998; Sanders \& Horn, 1994; Wright, Horn, \& Sanders, 1997). The least effective teachers add almost nothing to the students' knowledge in one year, and the cumulative effects of several years of being taught by such teachers can be devastating for the students' ability to cope with the complex requirements of the knowledge society.

The purpose of our study was therefore to analyse the research on educational productivity in order to determine the most important teacher competencies related to student achievement. The concept of competencies is defined as an individual's ability to successfully meet complex demands in a particular context through the mobilisation of psychosocial prerequisites (including cognitive and non-cognitive aspects) (Rychen \& Salganick, 2003, p. 43). Competencies are therefore comprised of a cognitive level (the ability of complex thinking and resolving problems, as well as using the knowledge in a certain area), an emotional-motivational level (attitudes, values, readiness to take action) and a behavioural level (the ability to activate and use one's potential in complex 
situations) (Weinert, 2001; Peklaj, 2010). The concept of teacher competencies was used in our study to describe complex instructional, classroom management, communication, problem-solving and assessment methods, techniques and strategies that teachers have to use in order to meet the complex demands of their teaching.

The model of teacher competencies was developed to serve as a framework for understanding the synergetic effects of teacher competencies on student achievement.

\section{A model of teacher competencies}

In order to synthesise information from such a large and diverse field of research, a framework was needed to guide the inquiry and reflection upon research results linking teacher competencies and student achievement. The starting point for developing a model was the notion that teachers have to promote overall student development and therefore must take into account the students' (meta)cognitive, affective-motivational and social processes.

Students and the processes that take place when students are engaged in learning activities were put at the centre of the teacher's interest in the classroom and at the centre of the model. Students are included in classroom work with their (meta)cognitive processes: they process information and solve problems, they try to remember the learning content, and they develop concepts by classifying, comparing and contrasting different aspects of objects and processes. They also regulate their own learning by planning, monitoring, evaluating and correcting learning tasks and processes. Furthermore, students in the class activate their affective-motivational processes when they set goals, develop attitudes towards teachers, subjects and peers, and develop interests and values related to their education. The third level of students' processes includes social processes. Students form relationships with the teacher and their peers in the classroom and school, they struggle to achieve high social status among peers and use various social skills to achieve their goals. All of these processes in the classroom lead to the best outcomes and the best student achievement when they are balanced and work in synergy. In order to achieve the best outcomes in students, teachers have to be focused on all there levels of processes in their teaching, taking each of them into account. For example, teaching focused only on cognitive goals (e.g., high grades) and neglecting the other two levels could lead to competition in the class, the rejection of some students, lower cohesiveness in the class, negative attitudes, low motivation and consequently lower achievement than could be achieved by taking into account all of the processes in class. 
Teacher competencies as a requirement for achieving synergetic effects in students are thus organised into three groups: teacher competencies for promoting cognitive processes (e.g., knowledge in the broadest sense as well as (meta)cognitive strategies), teacher competencies for promoting affective-motivational processes, and teacher competencies for promoting social processes in students. The model is presented in Figure 1.

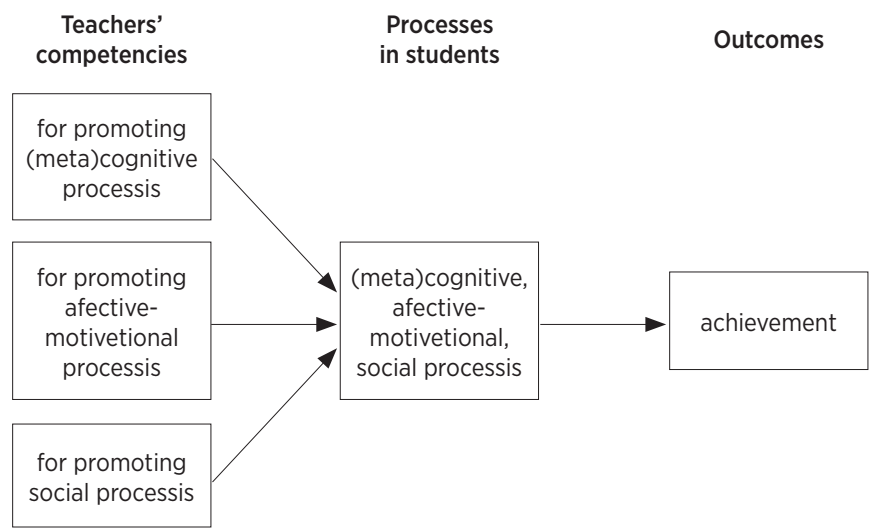

Figure 1. Model of teacher competencies and their effects on student achievement

In the present article, our interest will be focused on the effects of teacher competencies that have an impact on student achievement through students' (meta)cognitive, affective-motivational and social processes. Since competencies are defined as complex abilities with which an individual successfully meets the demands in a particular context, and given that these competencies have cognitive as well as non-cognitive aspects (Rychen \& Salganick, 2003), the literature search was also focused on the connection between cognitive and noncognitive aspects of teachers' work in the classroom and student achievement. It included the concepts of teaching strategies, teacher methods and activities (classroom management, communication, problem solving), teacher values and attitudes, and the relationship of these concepts to student achievement. The literature search comprised meta-analyses and other synthetic studies investigating the effects of teaching, teacher methods and activities in the classroom on student achievement. The ERIC and PsychArticles databases were used, as well as four extensive review studies: Beesley and Apthrop, (2010), Hattie (2009), Marzano, Gaddy and Dean (2000) and Walberg (2006). The research included different research designs, from descriptive, quasi-experimental to 
experimental. In the descriptive studies, differences between teachers with different levels of competencies were observed, while, in the experimental (or quasi-experimental) studies, teachers who used certain methods or strategies in their teaching were compared with teachers who did not use them. The different teacher competencies, or the methods and strategies they used, were evaluated in terms of their effect on student achievement. Student achievement was measured with tests (teacher-made, experimenter-made or standardised), grades or other student output (e.g., essays, projects). Effect sizes were usually expressed in Cohen $d$ values as the mean difference between two groups in standard deviation units. These values tell us the extent of standard deviation to which the result in the achievement test by the experimental group using a certain method in the classroom will increase or decrease from the average result in the control group. Effect sizes around 0.20 are small, 0.50 are moderate and o.80 are large (Cohen, 1988). Sometimes effect sizes are expressed in Hedges $g$, which takes into account correction for small sample sizes (Hedges \& Olkin, 1985). Hattie (2009) suggested that, for educational practice, effect sizes larger than 0.40 represent evident improvement in the measured variable. In terms of achievement, this effect size means greater than average student gain in one school year. In longitudinal studies in the US and New Zealand, the average effect sizes were $d=0.24$ and $d=0.35$, respectively (Hattie, 2009). Therefore, the effect size of 0.40 was used as a criterion for the inclusion of teacher competency effects in our analysis, as well.

In the further analysis, the results are organised into three sections: (1) teacher competencies for promoting students' cognitive and metacognitive processes, (2) teacher competencies for promoting affective-motivational processes, and (3) teacher competencies for promoting social processes. In each section, a summary of the analysis is presented in tables consisting of four columns (from left to right): the teacher competencies, the processes in students that are influenced by these teacher competencies, the effects of the teacher competencies on student achievement (i.e., effect sizes expressed in $d$ or $g$ values), and the author(s) of the review study or meta-analysis.

\section{Teacher competencies for promoting (meta)cognitive processes in students}

The bulk of the research on teacher factors and student outcomes is related to promoting cognitive and metacognitive processes in students. Thus, teacher competencies related to cognitive and metacognitive processes that enable students to process information more efficiently are discussed first. 
Teachers' instructional competencies are organised according to the sequence most commonly used in an average class. They can influence students' metacognitive processes (i.e., planning, monitoring, evaluation, regulation; Hacker, 1998; Kluwe, 1982) or cognitive processes.

Table 1. Effects of teacher competencies for facilitating (meta)cognitive processes and outcomes in students

\begin{tabular}{|c|c|c|c|}
\hline Teacher competencies & $\begin{array}{l}\text { Processes in } \\
\text { students }\end{array}$ & $\begin{array}{l}\text { Achievement effect } \\
\text { size }-d(g)\end{array}$ & Research \\
\hline $\begin{array}{l}\text { Assessment of previous } \\
\text { knowledge }\end{array}$ & $\begin{array}{l}\text { Metacognitive - } \\
\text { planning }\end{array}$ & 0.48 & Walberg (2006) \\
\hline $\begin{array}{l}\text { Previous knowledge } \\
\text { activation }\end{array}$ & $\begin{array}{l}\text { Metacognitive - } \\
\text { planning }\end{array}$ & 0.57 & Marzano et al. (2000) \\
\hline Defining learning goals & $\begin{array}{l}\text { Metacognitive - } \\
\text { planning }\end{array}$ & 0.56 & Hattie (2009) \\
\hline Verbal clarity & Cognitive & 0.75 & Hattie (2009) \\
\hline Posing questions & Cognitive & 0.46 & Hattie (2009) \\
\hline $\begin{array}{l}\text { Hypotheses setting and } \\
\text { testing }\end{array}$ & Cognitive & $0.60,0.46(g)$ & $\begin{array}{l}\text { Walberg (2006); Allen } \\
\text { (2010) }\end{array}$ \\
\hline $\begin{array}{l}\text { Identifying similarities } \\
\text { and differences }\end{array}$ & Cognitive & $1.31,1.61,0.65(g)$ & $\begin{array}{l}\text { Marzano et al. (2000); } \\
\text { Walberg (2006); } \\
\text { Apthorp (2010) }\end{array}$ \\
\hline $\begin{array}{l}\text { Use of nonverbal aids } \\
\text { (pictures, maps, graphs), } \\
\text { concept mappings }\end{array}$ & Cognitive & $0.75,0.57$ & $\begin{array}{l}\text { Walberg (2006); } \\
\text { Hattie, (2009) }\end{array}$ \\
\hline $\begin{array}{l}\text { Use of ICT (video, } \\
\text { animations) }\end{array}$ & Cognitive & 0.52 & Hattie (2009) \\
\hline Formative feedback & $\begin{array}{l}\text { Metacognitive } \\
\text { - monitoring, } \\
\text { evaluation, regulation }\end{array}$ & $0.73,0.94,0.76(g)$ & $\begin{array}{l}\text { Hattie (2009); Walberg } \\
\text { (2006); Igel, Clemons, } \\
\text { \& Apthorp (2010) }\end{array}$ \\
\hline $\begin{array}{l}\text { Homework with teacher's } \\
\text { comments }\end{array}$ & $\begin{array}{l}\text { Metacognitive } \\
\text { - monitoring, } \\
\text { evaluation, regulation }\end{array}$ & 0.83 & Walberg (2006) \\
\hline
\end{tabular}

At the beginning of the class, the teacher activates the students' cognitive structure by posing questions and explicitly setting the learning goals for that specific class (Hattie, 2009; Walberg, 2006; Marzano et al., 2000), enabling the students to connect their existing knowledge with the new information. Thus, the teacher launches the first step in the students' metacognitive process, i.e., their awareness of the information and concepts they already know, and their awareness of what they do not yet know. Research consistently shows effects around 0.50 on student achievement if the teacher systematically stimulates the students' prior knowledge. 
The next section of teacher competencies is related to information processing and helping students to integrate information and store it in the longterm memory in such a way that they will be able to retrieve it when needed. One of the necessary conditions for high student achievement is the teacher's verbal clarity, the appropriateness of the language they use in explaining the learning matter and in giving directions and requirements (Hattie, 2009). According to Hattie (2009), posing questions related to learning content is an important teacher competence that improves achievement. The quality of the questions asked is even more important for the students' cognitive processes than the quantity. Higher-level questions that require classification, comparison, and creation of metaphors and analogies lead to higher achievement. Research has revealed that the greatest effects on student knowledge are achieved by promoting identification of similarities and differences in content (Apthorp, 2010; Marzano et al., 2000; Walberg, 2006), thus enabling students to develop more complex schemas, highly connected knowledge and deeper levels of understanding (Apthorp, 2010). The development and testing of hypotheses (Allen, 2010; Walberg, 2006) by promoting inductive and deductive thinking have very similar effects. Students will be better able to transfer knowledge to other situations and will have a better understanding of lesson concepts (Allen, 2010).

In addition to verbal clarity and systematic explanations, higher student knowledge is also related to the teacher's use of visual aids in instruction (Hattie, 2009; Walberg, 2006). Nonverbal aids such as pictures, maps and graphs enable students to use both verbal and nonverbal channels in working memory, thus increasing the possibility of storing information in long-term memory more efficiently. Concept maps in the form of visual organisers (e.g., flowcharts, taxonomies, V-diagrams) make relationships between information and concepts more evident and promote meaningful learning and retention (Dexter, Park, \& Hughes, 2011). Dexter and his associates (Dexter et al., 2011) found this to be very effective in students with learning disabilities. Effect sizes for the use of graphic organisers on achievement in science were 1.05, with the effect also persisting in delayed testing $(g=0.88)$. Large effects sizes were also found in meta-analyses taking into account regular classes (i.e., $g=1.27$; Kablan, Topan, \& Erkan, 2013). In some cases, teachers could also use concrete manipulatives in addition to pictures, e.g., in teaching mathematics for students on a concrete operational level ( $d=0.45$; Carbonneau, Marley, \& Selig, 2013). Recent meta-analysis of spatial skill intervention showed an effect size of $g=0.47$ for improvement of spatial skills (Uttal et al., 2013). These results were found for interventions executed by trainers or teachers, for subjects of different ages, for both sexes, and for interventions that used video games or spatial tasks. 
Thus, teachers should systematically use visual aids in their teaching, while at the same time developing spatial skills in order to improve student knowledge.

Research has also shown that supporting teaching with the use of information technology (IT) is important for achieving even better effects in student knowledge $(d=0.42)$ at the K-12 grades level (Tamim, Bernard, Borokhovski, Abrami, \& Schmid, 2011). However, the use of IT does not in itself guarantee better student knowledge; teachers must use it thoughtfully in well-planned learning situations. Research has demonstrated (Hattie, 2009) the best effect on achievement when the use of IT is combined with teacher explanations, when it includes different tutorial systems that lead students through the learning process and give them an opportunity to rehearse and get feedback, when learning tasks are challenging for students, and when teachers receive appropriate training for the use of IT in teaching. Therefore, teachers should constantly improve their IT competencies in order to use them in instruction in such a way that promotes student knowledge and achievement at an optimal level.

The next group of teacher competencies is again connected with students' metacognitive processes, with the regulation of their thinking and learning. This group concerns teacher feedback (Hattie, 2009; Igel, Clemons, \& Apthorp, 2010; Marzano et al., 2000; Walberg, 2006), especially when it contains information about the correctness of students' reasoning or performance, and about the next steps for further improvement. Feedback helps students to understand the necessary changes required in order to improve learning, but must be informative and descriptive rather than evaluative if it is to support student self-regulation (Igel et al., 2010). Students can also get feedback on homework, which was found to have a larger effect on secondary school student achievement than on primary school students (Cooper, Robinson, \& Patall, 2006). Marzano (2003) also suggests that teachers should give students purposeful, appropriately difficult homework, ensuring a high level of probability that they will successfully complete it with appropriate parental support, without requiring parents to become teachers.

One often emphasised teacher competency is the ability to promote students' self-regulative learning. Self-regulation enables students to undertake lifelong learning and to adequately respond to rapid changes in the environment, thus helping them to successfully cope with these changes. Learning how to learn is one of eight key competencies that should be acquired during the period of schooling (Recommendations of the European Parliament and of the Council of $18^{\text {th }}$ December 2006 on key competencies for lifelong learning, 2006), which is why we also analyse the effects of promoting students' self-regulation on student achievement. Contemporary perspectives on self-regulative learning emphasise that self-regulation consists of cognitive, metacognitive and affective-motivational 
processes, and that it is always influenced by social context (Boekaerts, 1997; Garcia \& Pintrich, 1994; Schunk \& Zimmerman, 1998). Our analysis will therefore include the effects of teacher competencies for promoting (meta)cognitive as well as motivational self-regulation on student achievement.

Various interventions promoting self-regulation have shown the positive effects of self-regulation on student achievement (Dignath, Buettner, \& Langfeldt, 2008; Dignath \& Büttner, 2008; Hattie, 2009; Marzano et al., 200o; Perry, Alberg, \& Tung, 2012; Walberg, 2006). The effects on performance were greater when the interventions were researcher-directed $(d=0.86)$ rather than teacher-directed $(d=0.46)$. The greatest effects were found in mathematics performance, with $d$ $=0.99$ for research-directed intervention and $d=1.00$ for teacher-directed intervention (Dignath, Buettner, \& Langfeldt, 2008). Dignath and Büttner (2008) reported that the best effects on achievement were found when self-regulation was promoted with a combination of metacognitive, cognitive and motivational strategies. Teachers can facilitate self-regulative learning by scaffolding, providing feedback, providing support for self-regulation or by directly teaching cognitive and metacognitive strategies (Seidel \& Shavelson, 2007).

Table 2. Effects of teacher promotion of (meta)cognitive strategies on student achievement

\begin{tabular}{|c|c|c|c|}
\hline $\begin{array}{l}\text { Teacher competencies } \\
\text { for development of } \\
\text { self-regulation }\end{array}$ & $\begin{array}{l}\text { Processes in students - } \\
\text { strategies }\end{array}$ & $\begin{array}{l}\text { Achievement } \\
\text { effect size - } \\
d(g)\end{array}$ & Research \\
\hline $\begin{array}{l}\text { Planning and goal } \\
\text { setting }\end{array}$ & $\begin{array}{l}\text { Metacognitive strategies } \\
\text { - planning }\end{array}$ & $0.49,0.60$ & $\begin{array}{l}\text { Lavery (2008, in Hattie, } \\
\text { 2009); Dignath et al. (2008) }\end{array}$ \\
\hline Self-instructions & $\begin{array}{l}\text { Metacognitive strategies } \\
\text { - planning, monitoring }\end{array}$ & 0.62 & $\begin{array}{l}\text { Lavery (2008; in Hattie, } \\
\text { 2009) }\end{array}$ \\
\hline Monitoring & $\begin{array}{l}\text { Metacognitive strategies } \\
\text { - monitoring }\end{array}$ & $\begin{array}{l}0.45,0.78 \\
0.91\end{array}$ & $\begin{array}{l}\text { Lavery (2008, in Hattie, } \\
\text { 2009); Perry et al. (2012); } \\
\text { Dignath et al. (2008) }\end{array}$ \\
\hline Self-evaluation & $\begin{array}{l}\text { Metacognitive strategies } \\
\text { - evaluation }\end{array}$ & $0.62,0.69$ & $\begin{array}{l}\text { Lavery (2008, in Hattie, } \\
\text { 2009); Dignath et. al. } \\
\text { (2008) }\end{array}$ \\
\hline Taking records, notes & $\begin{array}{l}\text { Cognitive strategies - } \\
\text { rehearsal }\end{array}$ & $\begin{array}{l}0.59,1.00 \\
0.90(g)\end{array}$ & $\begin{array}{l}\text { Lavery (2008, in Hattie, } \\
\text { 2009); Marzano et al. } \\
\text { (2000); Igel, Clemons, } \\
\text { Apthorp, \& Bachler, 2010) }\end{array}$ \\
\hline $\begin{array}{l}\text { Rehearsing and } \\
\text { memorising }\end{array}$ & $\begin{array}{l}\text { Cognitive strategies - } \\
\text { rehearsal }\end{array}$ & 0.57 & $\begin{array}{l}\text { Lavery (2008 in Hattie, } \\
\text { 2009) }\end{array}$ \\
\hline $\begin{array}{l}\text { Organising and } \\
\text { transforming }\end{array}$ & $\begin{array}{l}\text { Cognitive strategies - } \\
\text { elaboration }\end{array}$ & $0.85,0.84$ & $\begin{array}{l}\text { Lavery (2008, in Hattie, } \\
\text { 2009); Dignath et al. (2008) }\end{array}$ \\
\hline Concept mapping & $\begin{array}{l}\text { Cognitive strategies - } \\
\text { elaboration, organisation }\end{array}$ & 0.57 & Hattie (2009) \\
\hline
\end{tabular}


Intervention research on self-regulation has shown that metacognitive and cognitive strategies can have substantial effects on cognitive outcomes in students (Ciu, 1998; Hattie, 2009; Perry et al., 2012). Lavery (2008, in Hattie, 2009) found that the best results were achieved in strategies that are activated in the "forethought" phase of self-regulation according to the social-cognitive models of self-regulation (Schunk \& Zimmerman, 1998; Zimmerman, 2000), the phase in which students think about upcoming learning tasks. The goals students set in this phase serve as criteria by which they judge how successful they have been in the learning situation, what they have to change and how (Wigfield, Klauda, \& Cambira, 2011). Self-instructions, i.e., verbalising the steps of problem solving or another given task, also proved to be a successful metacognitive strategy for guiding the steps in the performance phase of self-regulation (Lavery, 2008, in Hattie, 2009). Proceeding towards previously set goals helps students focus their attention and monitor progress. However, self-monitoring is not enough for high achievement; all of the necessary steps must be taken in the reaction and reflection phase of self-regulation: firstly, reflection on one's own performance, then judgment of its correctness and success according to the goals set, and finally corrections have to be made when necessary.

Teachers must therefore support students in learning how to set proximal as well as distal goals in order to achieve successful self-regulation. They have to teach them to use self-instructions to help them monitor the course of their actions in learning tasks and to check their work before they finish it and hand it in. Teachers must also emphasise the importance of evaluation and correction of the discrepancies between previously set goals and the actual performance. The research on facilitating self-regulation has also demonstrated higher effect sizes when intervention includes reflection upon metacognitive strategies and explicitly shows students the benefit of using these strategies (Dignath, Buetner, \& Langfeldt, 2008).

In addition to metacognitive strategies, students can use various cognitive strategies to store information in the long-term memory. Research shows that rehearsal, elaboration and organisation strategies considerably improve student performance (Hattie, 2009; Lavery, 2008, in Hattie, 2009; Dignath et al., 2008). Teachers have to convince students that rehearsing is an important strategy, and that to be able to use the learning matter in the future it is not enough just to hear or read it once. An even more challenging mission for the teachers is to persuade students to take notes in the classroom, which will help them be successful in learning. Students often believe that everything can be found on the Internet, and they therefore do not need to put any effort 
into note-taking or rehearsing. Teaching students how to take notes and how to rehearse to be effective is essential. Organising learning matter, looking for differences and similarities, summarising by selecting, sorting and combining information, outlining major concepts and organising them according to their importance of generality improves the students' comprehension of information (Igel et al., 2010). Research on intervention in self-regulation also shows that researcher-directed interventions yield better results than teacher-directed interventions (Dignath et al., 2008). In the future, more emphasis should therefore be placed on training teachers how to promote self-regulation in students. If teachers teach strategies connected with domain-specific knowledge during everyday classes, students will be better able to see the relevance of strategy use, which will increase the possibility of their using the strategies in the future.

\section{Teacher competencies for promoting affective-motiva- tional processes in students}

Learning processes in the classroom are not only related to the cognitive level, they are always embedded in an affective context. In school, students develop positive or negative attitudes toward their teachers and the subjects taught; they either enjoy learning or they are bored in class. This emotional context influences their learning performance to a great extent. The effects of student-teacher relationships on achievement have been studied with direct observation and with evaluations of these relationships by teachers, students and parents. Research has constantly demonstrated significant positive effects of positive teacher-student relationships on student achievement (Cornelius White, 2007; Hattie, 2009; Hattie \& Clinton, 2008). Positive relationships were evident in teachers' non-directivity, in their acceptance and appreciation of different students' attitudes and contributions, and in their way of developing an open and positive climate in the class, so that students are not afraid of asking questions and participating with their own solutions. Teacher empathy and warmth, their ability to adapt to individual differences, is also an inherent dimension of a good relationship (Cornelius White, 2007). Students have to perceive these dimensions in teachers' behaviour in order for them to have an effect on achievement. If teachers want to gain the respect of the students, they have to show the students respect (Hattie \& Clinton, 2008). 
Table 3. Effects of teachers' development of affective-motivational processes on student achievement

\begin{tabular}{llll}
\hline $\begin{array}{l}\text { Teacher competencies for } \\
\text { development of affective- } \\
\text { motivational processes }\end{array}$ & $\begin{array}{l}\text { Processes in } \\
\text { students }\end{array}$ & $\begin{array}{l}\text { Achievement } \\
\text { effect size - d }\end{array}$ & Research \\
\hline $\begin{array}{l}\text { Positive relationships with } \\
\text { students }\end{array}$ & $\begin{array}{l}\text { Affective } \\
\text { processes }\end{array}$ & 0.72 & Hattie (2009) \\
$\begin{array}{l}\text { Non-directivity } \\
\text { Empathy }\end{array}$ & 0.75 & Cornelius White (2007) \\
Warmth & 0.68 & Cornelius White (2007) \\
$\begin{array}{l}\text { Respect for students } \\
\text { Adapting to individual differences }\end{array}$ & 0.67 & Cornelius White (2007) \\
$\begin{array}{l}\text { Positive attitude towards the } \\
\text { subject and teaching }\end{array}$ & 0.61 & Hattie \& Clinton (2008) \\
High expectations - challenges & $\begin{array}{l}\text { Motivational } \\
\text { processes }\end{array}$ & 0.41 & Cornelius White (2007) \\
Self-efficacy & & 0.90 & Hattie \&Clinton (2008) \\
\hline
\end{tabular}

One of the most effective teacher characteristics that influences student outcomes is their passion for their own subject and for teaching and learning (Hattie \& Clinton, 2008), as evident in their everyday teaching (Frenzel, Goetz, Lủdtke, Pekrun, \& Sutton, 2009; Hattie \& Clinton, 2008). Students can sense the teacher's enthusiasm in their verbal and nonverbal communication about the teaching content, as well as in their remarks related to their reading in the field, to the latest findings and their relevance for student work in the class.

From the motivational point of view, the teacher's ability to set relatively high learning goals that represent a challenge for students (Hattie \& Clinton, 2008) is another important teacher competence. Teachers also have to show students that they believe in their ability to learn and achieve these goals. Therefore, learning goals must be achievable, while at the same time being high enough to require effort from the students in attaining them. Attaining such goals also increases student self-efficacy, encouraging persistence in learning and, consequently, achievement of the goals (Hattie, 2009).

Some teacher competencies related to students' affective-motivational processes are connected with the students' motivational self-regulation, especially their action control (Dignath et al., 2008). Research has shown (Dignath et al., 2008) that the effects of self-regulation interventions are higher when they include cognitive, metacognitive as well as motivational components of self-regulation. The first important motivational strategy is successful time regulation. Time regulation includes the students' ability to plan and correctly 
judge the amount of time required for learning a task, and above all the ability to delay gratification (Mischel \& Gilligan, 1964). Teachers have to systematically train students how to set proximal and more distal goals, together with the use of volitional strategies such as ignoring distractions and ruminations about past mistakes (Zimmerman, 2000).

Table 4. Effects of teacher development of affective-motivational strategies on student achievement

\begin{tabular}{llll}
\hline $\begin{array}{l}\text { Teacher competencies for } \\
\text { development of affective- } \\
\text { motivational strategies }\end{array}$ & Processes in students & $\begin{array}{l}\text { Achievement } \\
\text { effect size }-\boldsymbol{d}\end{array}$ & Research \\
\hline Self-consequences & $\begin{array}{l}\text { Affective- motivational } \\
\text { strategy }\end{array}$ & 0.70 & $\begin{array}{l}\text { (Lavery, 2008, in } \\
\text { Hattie, 2009) }\end{array}$ \\
Help seeking & $\begin{array}{l}\text { Affective- motivational } \\
\text { strategy }\end{array}$ & 0.60 & $\begin{array}{l}\text { (Lavery, 2008, in } \\
\text { Hattie, 2009) }\end{array}$ \\
Time management & Organisational strategy & 0.44 & (Lavery, 2008, in \\
\hline
\end{tabular}

Effective self-regulation can be also achieved through the use of selfconsequencing (Lavery, 2008, in Hattie, 2009). Students can imagine or arrange a reward or punishment for successfully finishing or failing to finish a task. Training on self-consequencing includes choosing appropriate rewards for achievement. Social rewards (e.g., taking some time to talk to one's best friend after finishing a school project) are better than material rewards.

In order to develop students' motivational self-regulation, teachers must also facilitate help-seeking strategies as a way to improve performance and to achieve excellence in a particular field. The teacher can promote this by showing that help-seeking is a successful way of increasing learning, and not merely an expression of incompetence or a lack of ability (Nelson-LeGall, 1992). This will enable students to include this strategy in their repertoire of self-regulation for the prevention of underachievement.

\section{Teacher competencies for promoting social processes in students}

The last group of teacher competencies that have an important influence on student achievement is connected with the social process in the classroom. In their meta-analysis, Roseth, Johnson and Johnson (2008) found that improvement of the social climate and social relations in the classroom by 1 $S D$ (standard deviation) can boost achievement by $0.63 S D$. The teacher can 
improve social relations in the classroom by promoting social inclusion and cohesion. Social inclusion is related to the feeling that all members of the class (teacher and students) strive towards the same goal and nobody is excluded (Hattie, 2009). Teachers have to prevent the development of cliques and friction in their classes by actively involving all of the students in the class work. They can use cooperative learning methods to achieve this goal, especially by structuring social interdependence in small groups as well as with various methods for developing an awareness of class membership (Johnson \& Johnson, 1987; Kagan, 1989; Peklaj \& Vodopivec, 1999). Social interdependence exists in a group when students perceive that their individual and group goals are connected in such a way that they cannot achieve their individual goals if the group as a whole does not achieve its goal as well (Johnson \& Johnson, 1992).

Table 5. Effects of teacher development of social processes on student achievement

\begin{tabular}{llll}
\hline $\begin{array}{l}\text { Teacher competencies } \\
\text { for development of social } \\
\text { processes }\end{array}$ & Processes in students & $\begin{array}{l}\text { Achievement } \\
\text { effect size }-\boldsymbol{d}\end{array}$ & Research \\
\hline Classroom climate & Social processes & 0.63 & $\begin{array}{l}\text { Roseth, Johnson, \& } \\
\text { Johnson (2008) }\end{array}$ \\
Classroom cohesion & 0.53 & Hattie (2009) \\
Classroom management & $0.52,0.52$ & $\begin{array}{l}\text { Marzano (2000); } \\
\text { Hattie (2009) }\end{array}$ \\
Peer influences & 0.53 & Hattie (2009) \\
\hline
\end{tabular}

Closely related to social processes in the class are teachers' classroom management competencies in the broadest sense. Efficient classroom management includes teachers structuring classroom activities in such a way that learning activities take place smoothly, without unnecessary delays, and without empty time when nothing is happening in the class. The teacher must be aware of the processes in the class and act both preventively and responsively to avoid disruptions; it is better to take action before anything happens that would disturb the learning process. Establishing classroom rules about desired behaviour in the class can prevent a lot of problems (Marzano, 2000; Hattie, 2009). It is very important that teachers also react to inappropriate behaviour in the class, and that they use rewards and consequences. Marzano (2000) reports that the combined use of punishment and reinforcement significantly reduces student misbehaviour $(d=97)$. A reduced level of misbehaviour allows for the development of an optimal learning environment in which students can feel safe and focus on learning goals. 
Teachers' social-related competencies should also focus on developing the students' academic social skills, which are related to higher student achievement and to their better acceptance in the class. Academic social skills concern students' relationships with the teacher and with their peers, including cooperative skills (giving and receiving help, following instructions, sharing things with others, etc.), assertiveness (taking initiative, asking questions, etc.) and self-control (appropriate response to poor grades and to peers' behaviour: put-downs, rejections, etc.). Students with good social skills can use the educational environment and its potential to a greater extent than students with poor academic social skills. They also develop more friendships and therefore use peers' care, help and support in the class to a larger extent, which consequently enhances their achievement.

Konold, Jamison, Stanton-Chapman and Rimm-Kaufman (2010) found that students' social skills predict up to 10 percent of variance in their achievement. A recent study in the field of economics (Chattey, Friedman, Hilger, Saez, Whitemore Schanzenbach, \& Yaga, 2010; Chetty, Friedman, \& Rockoff, 2011) revealed the economic value of teacher competencies. The research used data from the project STAR (Student Teacher Achievement Ratio) from Tennessee, and attempted to answer the question of the influence that the quality of education at the beginning of school had on the participants when they were 27 years old. The results were very informative. It was found that the effects of more experienced teachers were evident in their former students' income. The most important teacher competencies and their effects were not those that operate through cognitive processes (that is, better knowledge), but those that operated through the development of students' academic social skills (that is, effort investment, initiative, interest and appropriate behaviour). An increase of $1 S D$ in these skills leads to a $0.20 S D$ increase in income per year.

\section{Conclusions and implications for teacher education}

The aim of our analysis was to examine teacher competencies and their effects on achievement through the prism of educational research. A model of teacher competencies was developed to serve as a framework for structuring the analysis. The model consists of three elements: teacher competencies, processes in students that are affected by teacher competencies, and outcomes in students (i.e., achievement). At the centre of the model are students' processes in the classroom, that is, (meta)cognitive, affective-motivational and social processes, which must be balanced in order to achieve the best student outcomes. Teacher competencies are also organised into three groups according to the processes they promote. 
The analyses of research related to teacher competencies and students' outcomes revealed the importance of taking into account all three levels of students' processes in the classroom. The inclusion criteria for a teacher competence were $d$ values producing achievement higher than the average students' gain in a school year. Comparison of teacher competencies revealed moderate to large effects of teachers' instructional competencies related to students' cognitive and metacognitive processes on student achievement, as well as of teacher competencies to promote affective-motivational processes. The effects of teacher competencies for promoting social processes on student achievement are moderate. On the basis of our analysis, we can conclude that all three groups of teacher competencies are important for student gains. We can also assume that the best results in students could be achieved by facilitating the synergetic effects of (meta)cognitive, affective-motivational and social processes in students. This has been confirmed by other studies. For example, differences in all three groups of competencies were found in research of the differences between future teachers who had passed and who had failed to pass the exam for a licenced teacher in the USA (Hattie \& Clinton, 2008). More competent teachers (i.e., teachers who passed the exam) had a deeper understanding of their subject, of teaching and of the effects of their own teaching on students. Furthermore, they had a sense of control in the classroom, they had high levels of passion for teaching and learning, they respected their students, and they developed a positive classroom climate that fostered learning.

The complexity of the competencies that promote student achievement brings very high requirements for teachers and makes teaching one of the most demanding professions. Our findings also have some practical implications for teacher education. Firstly, teaching requires a lot of very complex competencies that cannot be developed overnight; they must be developed in the course of well-executed pre-service and in-service training closely linked to practical work in the classroom. Therefore, the partnership between universities and schools is a necessary condition for successful teacher education. This partnership enables a curriculum based on a knowledge of student development, learning, social context and subject matter (Darling-Hammond, 2006).

Secondly, synergetic effects on students' outcomes require the development of complex instructional, management, assessment and communication competencies of teachers. Thus, in addition to the development of instructional competencies, a great deal of emphasis in teacher education and professional development should also be placed on the development of competencies related to affective and social processes, in order to equip teachers with the necessary tools for working with different students and for the development of 
optimal learning environments. Future teachers can develop these competencies by connecting theory and practice, through constant reflection on already achieved competencies, and through performance assessment based on professional standards.

\section{References}

Allen, J. (2010). Generating and testing hypotheses. In A. D. Beesley \& H. S. Apthorp (Eds.), Classroom instruction that works. Research report (pp. 114-129). McRel Making a Difference. Retrieved 18.08.2014 from http://eric.ed.gov/?id=ED543521 Apthorp, H. S. (2010). Identifying similarities and differences. In A. D. Beesley \& H. S. Apthorp (Eds.), Classroom instruction that works. Research report (pp. 14-31). McRel Making a Difference. Retrieved 18.08.2014 from http://eric.ed.gov/?id=ED543521 Beesley, A. D., \& Apthorp H. S. (2010). Classroom instruction that works. Research report. McRel Making a Difference. Retrieved 18.08.2014 from http://eric.ed.gov/?id=ED543521

Boekaerts, M. (1997). Self-regulated learning: a new concept embraced by researchers, policy makers, teachers and students. Learning and Instruction, 7(2), 161-186.

Carbonneau, K. J., Marley, S. C., \& Selig, J. P. (2013). A meta-analysis of the efficacy of teaching mathematics with concrete manipulatives. Journal of Educational Psychology, 105(2), 380-400. Chattey, R., Friedman, J. N., Hilger, N., Saez, E., Whitemore Schanzenbach, D., \& Yaga, D. (2010). How does your kindergarten classroom affect your earnings. Evidence from project STAR. NBER Working Paper Series. Paper NO. 16381. Retrieved 09.01.2011 from http://obs.rc.fas.harvard.edu/ chetty/STAR.pdf

Chetty, R., Friedman, J. N., \& Rockoff, J. E. (2011). The long-term impacts of teachers: Teacher value-added and student outcomes in adulthood. NBER Working Paper Series. Working Paper 17699. Cambridge, MA: National Bureau of Economic Research. Retrieved 09.09.2014 from http://obs. rc.fas.harvard.edu/chetty/value_added.pdf

Chiu, C. W. T. (1998). Synthesizing metacognitive interventions: What training characteristics can improve reading performance. Paper presented at symposium, "Metacognition: Assessment \& Training", at the Annual Meeting of the American Educational Research Association, in San Diego, California. April 13-17, 1998. Retrieved 20.08.2014 from http://files.eric.ed.gov/fulltext/ED420844.pdf Cohen, J. (1988). Statistical Power Analysis for the Behavioral Sciences (2nd ed.). New Jersey: Lawrence Erlbaum Associates.

Cooper, H., Robinson, J. C., \& Patall, E. A. (2006). Does homework improve academic achievement? A synthesis of research, 1987-2003. Review of Educational Research, 76(1), 1-62.

Cornelius White, J. (2007). Learner-cantered teacher-students relationships are effective: A metaanalysis. Review of Educational Research, 77(1), 113-143.

Daling-Hammond, L. (2006). Powerful teacher education: Lessons from exemplary programs. San Francisco, CA: Jossey-Bass. 
Dexter, D. D., Park, Y. J., \& Huges, C. A. (2011). A meta-analytic review of graphic organizers and science instruction for adolescents with learning disabilities: Implications for the intermediate and secondary science classroom. Learning Disabilities Research \& Practice, 26(4), 204-213

Dignath, C., \& Büttner, G. (2008).Components of fostering self-regulated learning among students. A meta-analysis of interventions at primary and secondary school level. Metacognition Learning, 3, 231-264.

Dignath, C., Buettner, G., \& Langfeldt, H. P. (2008). How can primary school students learn self-regulated learning strategies most effectively? A meta-analysis on self-regulation training programmes. Educational Research Review, 3, 101-129.

Frenzel, A. C., Goetz, T., Lüdtke, O., Pekrun, R., \& Sutton, R. (2009). Emotional transmission in the classroom: exploring the relationship between teacher and student enjoyment. Journal of Educational Psychology, 101(3), 705-716. DOI: 10.1037/aoo14695

Garcia, T., \& Pintrich, P. R. (1994). Regulating motivation and cognition in the classroom. The role of self-schema's and self-regulatory strategies. In D. H. Schunk \& B. J. Zimmerman (Eds.), Selfregulation of learning and performance: Issues and educational applications (pp. 127-153). Hilsdale, NJ: Erlbaum.

Hacker, D. J. (1998). Definitions and empirical foundations. In D. J. Hacker, J. Dunlosky, \& A. C. Graesser (Eds.), Metacognition in educational theory and practice (pp. 1-24). Mahwah, NJ: LEA. Hattie, J. A. C. (2009). Visible learning: A synthesis of over 800 meta-analyses relating to achievement. London: Rutledge.

Hattie, J. A. C., \& Clinton, J. (2008). Identifying accomplished teachers: A validation study. In L. Ingvarson \& J. A. C. Hattie (Eds.), Assessing teachers for professional certification. The first decade of the National Board of Professional Teaching Standards (pp. 313-344). Oxford, UK: Elsevier.

Haycock, K. (1998). Good teaching matters... a lot. Thinking K-16, 3(2), 1-14.

Hedges, L. V., \& Olkin, I. (1985). Statistical methods for meta-analysis. Boston: Academic Press. Igel, C., Clemens, T., \& Apthorp, H. (2010). Setting objective and providing feedback. In A. D. Beesley, \& H. S. Apthorp (Eds.), Classroom instruction that works. Research report (pp. 105-113). McRel Making a Difference. Retrieved 18.08.2014 from http://eric.ed.gov/?id=ED543521 Igel, C., Clemens, T., Apthorp, H., \& Bachler, S. (2010). Summarizing and note taking. In A. D. Beesley, \& H. S. Apthorp (Eds.), Classroom instruction that works. Research report (pp. 14-31). McRel Making a Difference. Retrieved 18.08.2014 from http://eric.ed.gov/?id=ED543521 Johnson, D. W., \& Johnson, R. T. (1987). Learning together and alone: Cooperative, competitive and individualistic learning. Englewood Cliffs: Prentice-Hall.

Johnson, D. W., \& Johnson, R. T. (1992). Positive interdependence: Key to effective cooperation. In R. Hertz-Lazarowitz \& N. Miller (Eds.), Interaction in cooperative groups: The theoretical anatomy of group learning (pp. 174-199). New York: Cambridge University Press.

Kablan, Z., Topan, B., \& Erkan, B. (2013). The effectiveness level of material use in classroom instruction: A meta-analysis study. Educational Sciences: Theory \& Practice, 13(3), 1638-1644. Kagan, S. (1989). Cooperative learning. Resources for teachers. San Juan Capistrano, CA: Resources for 
teachers.

Kluwe, R. H. (1982). Cognitive knowledge and executive control: Metacognition. In D. R. Griffin (Ed.), Animal mind - human mind (pp. 201-224). New York: Springer Verlag.

Konold, T. R., Jamison, K. R., Stanton-Chapman, T. L., \& Rimm-Kaufman, S. E. (2010). Relationships among informant based measures of social skills and student achievement: A longitudinal examination of differential effects by sex. Applied Developmental Science, 14(1), 18-34.

Marzano, R. J. (2000). A new era of school reform: Going where the research takes us. Aurora, CO: Mid Continent Research for Education and Learning.

Marzano, R. J. (2003). What works in schools: Translating research into action. Alexandria, Virginia: Association for Supervision and Curriculum Development.

Marzano, R. J., Gaddy, B. B., \& Dean, C. (2000). What works in classroom instruction. Aurora, Co: McREL. Retrieved 20.08.2014 from http://www.peecworks.org/peec/peec_research/Io1795EFA.3/ Marzano\%2oWhat_Works.pdf

Mischel, W., \& Gilligan, C. F. (1964). Delay of gratification, motivation for the prohibited gratification, and responses to temptation. Journal of Abnormal and Social Psychology, 69, 411-417. Nelson-LeGall, S. (1992). Children's instrumental help seeking: Is role in the social acquisition and construction of knowledge. In R. Hertz-Lazarowitz \& N. Miller (Eds.), Interaction in cooperative groups: The theoretical anatomy of group learning (pp. 49-70). New York: Cambridge University Press. Nye, B., Konstantopoulos, S., \& Hedges, L. V. (2004). How large are teachers effects? Educational Evaluation and Policy Analysis, 26(3), 237-257.

Peklaj, C. (2010). Teacher competencies in a knowledge society. In C. Peklaj (Ed.), Teacher competencies and educational goals (pp. 37-50). Schriften zur Bilduns- und Freizeitwissenschaft, Band 6. Aachen: Shaker Verlag.

Peklaj, C., \& Vodopivec, B. (1999). Effects of co-operative versus individualistic learning on cognitive, affective, metacognitive and social processes in students. European Journal of Psychology of Education, 14(3), 359-373.

Perry, V., Albeg, L., \& Tung, C. (2012). Meta-analysis of single-case design research on self-regulatory interventions for academic performance. Journal of Behavioral Education, 21, 217-229.

Recommendations of the European Parliament and of the Council of $18^{\text {th }}$ December 2006 on key competencies for lifelong learning (2006). Official Journal of the European Union, L 349/10, EN, 30. 12. 2006. Retrieved 21.01.2008 from http://eur-lex.europa.eu/LexUriServ/site/en/oj/2006/ I_39420061230enoo100018.pdf

Roseth, C. J., Johnson, D. W., \& Johnson, R. T. (2008). Promoting early adolescents' achievement and peer relationships: The effects of cooperative, competitive, and individualistic goal structures. Psychological Bulletin, 13(2), 233-246.

Rychen, D. S., \& Salganik, L. H. (2001). Defining and selecting key competencies. Seattle: Hogrefe \& Huber Publishers.

Rychen, D. S., \& Salganik, L. H. (2003). Key competencies for a successful life and a well-functioning society. Seattle: Hogrefe \& Huber Publishers. 
Sanders, W. L., \& Horn, S. P. (1994). The Tennessee value-added assessment system (TVAAS): Mixed model methodology in educational assessment. Journal of Personal Evaluation in Education, 8, 299-311.

Schunk, D. H., \& Zimmerman, B. J. (1998). Self-regulated learning. From teaching to self-reflective practice. New York: Guilford.

Seidel, T., \& Shavelson, R. J. (2007). Teaching effectiveness research in the past decade: The role of theory and research design in disentangling meta-analysis results. Review of Educational Research, $77(4), 454-499$.

Tamim, R. M., Bernard, R. M., Borokhovski, E., Abrami, P. C., \& Schmid, R. F. (2011). What forty years of research says about the impact of technology on learning: A second-order meta-analysis and validation study. Review of Educational Research, 8(1), 4-28.

Uttal, D. H., Meadow, N. G., Tipton, E., Hand, L. L., Alden, A. R., Warren, C., \& Newcombe, N. S. (2013). The malleability of spatial skills: A meta-analysis of training studies. Psychological Bulletin, 139(2), 352-402.

Walberg, H. J. (2006). Improving educational productivity: An assessment of extant research. In R. F Subotnik \& H. J. Walberg (Eds.), The scientific basis of educational productivity (pp. 103-160). Greenwich, Co: IAP.

Weinert, F. E. (2001).Concept of competence: A conceptual clarification. In D. S. Rychen \& L. H. Salganik (Eds.), Defining and selecting key competencies (pp. 45-66). Seattle: Hogrefe \& Huber Publishers.

Wigfield, A., Klauda, S. L., \& Cambira, J. (2011). Influences on the development of academic selfregulatory processes. In B. J. Zimmerman \& D. H. Schunk (Eds.), Handbook of self-regulation of learning and performance (pp. 33-48). New York: Rutledge.

Wright, S. P., Horn, S. P., \& Sanders, W. L. (1997). Teacher and classroom effects on student achievement. Implications for teacher evaluation. Journal of Personal Evaluation in Education, 11, $57-67$.

Zimmerman, B. J. (2000). Attaining self-regulation. A social cognitive perspective. In M. Boekaerts, P. R. Pintrich, \& M. Zeidner (Eds.), Handbook of self-regulation (pp. 13-41). San Diego, CA: Academic Press. 


\section{Biographical note}

Cirila Peklaj, PH.D., is full professor at the Department of Psychology, Faculty of Arts, University of Ljubljana. She teaches different undergraduate and graduate psychology courses: Psychology of teaching, Psychosocial relations in the class, Stress in school, Psychoeducational assessment. She also participates in in-service teacher education. Her research interests are related to the phenomena of learning and teachers education: cooperative learning, self-regulative learning, students' achievement, e-learning and teachers' competencies. She published several scientific articles, wrote monographs, university textbooks and contributed chapters to different books. 